\title{
A Patient with Fulminant Influenza-Related Bacterial Pneumonia Due to Streptococcus pneumoniae Followed by Mycobacterium tuberculosis Infection
}

\author{
Masafumi Seki ${ }^{1,2}$, Naofumi Suyama ${ }^{3}$, Kohji Hashiguchi ${ }^{4}$, Atsuko Hara ${ }^{1}$, Kosuke Kosai ${ }^{1}$, \\ Shintaro Kurihara ${ }^{2}$, Shigeki Nakamura ${ }^{1}$, Kazuko Yamamoto ${ }^{1,2}$, Yoshifumi Imamura ${ }^{1,2}$, \\ Koichi Izumikawa ${ }^{1,2}$, Hiroshi Kakaya ${ }^{1,2}$, Katsunori Yanagihara ${ }^{2}$, Yoshihiro Yamamoto ${ }^{2}$, \\ Hiroshi Mukae ${ }^{1}$, Takayoshi Tashiro ${ }^{1,2}$ and Shigeru Kohno ${ }^{1,2}$
}

\begin{abstract}
A 74-year-old man with poorly controlled diabetes mellitus was admitted to our hospital because of severe respiratory disturbance, fever, and sputum. We found massive consolidation of the right lung and nodular shadows on the left lung on chest X-ray, and detected influenza virus and Streptococcus pneumoniae antigen from a nasopharyngeal swab and urine sample, respectively. Co-infection with influenza virus and bacteria was suspected, and oseltamivir and biapenem were prescribed. Laboratory data improved after the addition of sivelestat sodium hydrate, an inhibitor of neutrophil-derived elastase; however, chest X-ray findings became worse on Day 8, and we administered $1 \mathrm{~g}$ methylprednisolone intravenously for two days. On Day 12, we detected Mycobacterium tuberculosis in the sputum, even though we did not previously detect any acid-fast bacilli, and started anti-tuberculosis drugs, such as isoniazid, rifampicin, ethambutol hydrochloride, and pyrazinamide; however, the patient died 12 days later. Severe influenza-related bacterial pneumonia with Streptococcus pneumoniae and subsequently secondary tuberculosis infection were finally suspected in this case. This was a very rare case in which additional tuberculosis infection was found in a patient with fulminant pneumonia due to co-infection of influenza virus and bacteria. It is necessary to observe patients with influenza carefully, especially when steroids are used, even if antibiotics are also administered.
\end{abstract}

Key words: influenza virus, co-infection, pneumonia, Streptococcus pneumoniae, Mycobacterium tuberculosis, steroid

(Inter Med 47: 2043-2047, 2008)

(DOI: 10.2169/internalmedicine.47.1473)

\section{Introduction}

Influenza virus infection is a major respiratory infectious disease that generally induces bronchitis (1-3). It causes an acute febrile illness with malaise and respiratory failure is sometimes lethal in the elderly if the bronchitis develops into pneumonia (4).

Influenza pneumonia has been classified into primary in- fluenza virus and bacterial infection-related types of pneumonia (4-8). The former type is due to the virus itself. Patients with this type usually report having shortness of breath, but no sputum. Chest X-ray findings show reticular shadows and respiratory disturbances rapidly progress. Steroids are usually used for treatment to improve inflammation of the lungs $(5,6)$. The latter type is due to mixed or secondary bacterial infection. The symptoms, including cough and sputum, are similar to those of bacterial pneumonia, and in-

\footnotetext{
${ }^{1}$ Department of Molecular Microbiology and Immunology, Nagasaki University Graduate School of Biomedical Sciences, Nagasaki, ${ }^{2}$ The Second Department of Internal Medicine, Nagasaki University School of Medicine, Nagasaki, ${ }^{3}$ Nagasaki Municipal Medical Center, Nagasaki and ${ }^{4}$ The Japan Red Cross, Nagasaki Atomic Bomb Hospital, Nagasaki

Received for publication July 4, 2008; Accepted for publication August 18, 2008

Correspondence to Dr. Masafumi Seki, seki@nagasaki-u.ac.jp
} 
Table 1. Laboratory Findings on Admission

\begin{tabular}{|c|c|c|c|c|c|c|c|}
\hline Parameters & Measurements & Parameters & Measurements & Parameters & Measurements & Parameters & Measurements \\
\hline Hematology & & Chemistry & & Serology & & $\begin{array}{l}\text { Blood gas } \\
\text { analysis }\left(\mathrm{O}_{2} 6 \mathrm{~L}\right. \\
\text { mask })\end{array}$ & \\
\hline $\mathrm{WBC}^{\mathrm{a}}$ & $12300 / \mathrm{mm}^{3}$ & $\mathrm{TP}$ & $6.3 \mathrm{~g} / \mathrm{dL}$ & KL-6 & $271 \mathrm{U} / \mathrm{mL}$ & $\mathrm{pH}$ & 7.411 \\
\hline $\mathrm{Neu}^{\mathrm{a}}$ & $95.3 \%$ & TB & $1.7 \mathrm{mg} / \mathrm{dL}$ & $\mathrm{RF}$ & $(-)$ & $\mathrm{PaO}_{2}$ & 65 Torr \\
\hline Mo & $1.1 \%$ & AST & $36 \mathrm{IU} / \mathrm{L}$ & ANA & $(-)$ & $\mathrm{PaCO}_{2}$ & 34 Torr \\
\hline $\mathrm{Eo}^{\mathrm{a}}$ & $0.1 \%$ & ALT & $15 \mathrm{IU} / \mathrm{L}$ & HBsAg & $(-)$ & $\mathrm{HCO}_{3}^{-\mathrm{a}}$ & $18.5 \mathrm{mEq} / \mathrm{L}$ \\
\hline $\mathrm{Ba}$ & $0.8 \%$ & LDH & $235 \mathrm{IU} / \mathrm{L}$ & $\mathrm{HCV} \mathrm{Ab}$ & $(-)$ & $\mathrm{BE}^{\mathrm{a}}$ & -5.8 \\
\hline $\mathrm{Hb}$ & $16.9 \mathrm{~g} / \mathrm{dL}$ & $\mathrm{CPK}$ & $512 \mathrm{IU} / \mathrm{L}$ & $\begin{array}{l}\text { Mycoplasma } \\
\text { antibody }\end{array}$ & $<40(-)$ & & \\
\hline \multirow[t]{9}{*}{ Plt } & $25.5 \times 10^{4} / \mathrm{mm}^{3}$ & Amy & $15 \mathrm{IU} / \mathrm{L}$ & $\beta$-D-glucan & $(-)$ & & \\
\hline & & $\mathrm{BUN}^{\mathrm{a}}$ & $41.9 \mathrm{mg} / \mathrm{dL}$ & $\begin{array}{l}\text { Aspergillus } \\
\text { antigen }\end{array}$ & $(-)$ & & \\
\hline & & $\mathrm{Cr}$ & $0.9 \mathrm{mg} / \mathrm{dL}$ & $\operatorname{IgE}$ & $212 \mathrm{IU} / \mathrm{mL}$ & & \\
\hline & & $\mathrm{Na}$ & $138 \mathrm{mEq} / \mathrm{L}$ & $\operatorname{IgG}$ & $2430 \mathrm{mg} / \mathrm{dL}$ & & \\
\hline & & $\mathrm{K}$ & $4.4 \mathrm{mEq} / \mathrm{L}$ & $\operatorname{Ig} \mathrm{A}$ & $624 \mathrm{mg} / \mathrm{dL}$ & & \\
\hline & & $\mathrm{Cl}$ & $97 \mathrm{mEq} / \mathrm{L}$ & $\operatorname{IgM}$ & $243 \mathrm{mg} / \mathrm{dL}$ & & \\
\hline & & $\mathrm{Ca}$ & $8.7 \mathrm{mEq} / \mathrm{L}$ & & & & \\
\hline & & $\mathrm{CRP}^{\mathrm{a}}$ & $39.53 \mathrm{mg} / \mathrm{dL}$ & & & & \\
\hline & & FBS $^{a}$ & $364 \mathrm{mg} / \mathrm{dL}$ & $\mathrm{HbA} 1 \mathrm{c}^{\mathrm{a}} 11.7 \%$ & & & \\
\hline
\end{tabular}

${ }^{\mathrm{a}}$ Measurements were out of normal range.

filtrative shadows appear on chest X-rays $(7,8)$. Synergic effects between the influenza virus and bacteria have been suggested and severe pneumonia frequently results in patients co-infected with the influenza virus and bacteria.

Here, we describe a patient who died of severe influenza pneumonia followed by tuberculosis. The patient's condition was initially diagnosed as mixed pneumonia due to influenza virus and Streptococcus pneumoniae, and antimicrobial drugs were administered. Laboratory data improved, whereas chest X-ray findings became worse. The addition of a steroid improved his symptoms; however, $M y$ cobacterium tuberculosis was detected and the patient died despite intensive treatment and administration of antituberculosis drugs.

\section{Case Report}

A 74-year-old man was admitted to the emergency ward in our hospital in March 2008 because of dyspnea, yellow sputum, and chills due to a high fever that he had had for two days. He had an old brain infarction and type-2 diabetes mellitus (DM) that was treated with a mixture of $30 \%$ regular insulin and $70 \%$ neutral protamine Hagedorn insulin (daily injections of 14 units before breakfast and 10 units before dinner).

A physical examination upon admission revealed a high body temperature $\left(38.6^{\circ} \mathrm{C}\right)$, moist rales on both anterior chest walls, and yellow sputum. Respiratory disturbance was obvious; $\mathrm{SpO}_{2}$ was $91 \%$ under $\mathrm{O}_{2}$ mask conditions and the patient was put on a ventilator the next day. Laboratory findings indicated severe inflammation as follows: white blood cells (WBC), 12,300/ $\mathrm{mm}^{3}$; neutrophils, $95.3 \%$; and Creactive protein $(\mathrm{CRP}), 39.53 \mathrm{mg} / \mathrm{dL}$ (Table 1). The creatine phosphokinase level was also elevated. We found a massive consolidation of the right lung and nodular shadows on the left lung (Fig. 1), and detected influenza virus type-A antigen from a nasopharyngeal swab. Streptococcus pneumoniae with phagocytosis was also found in gram staining of the sputum and its antigen was detected in urine at the time of hospital admission. Furthermore, $1 \times 10^{5} \mathrm{cfu} / \mathrm{mL}$ of Streptococcus pneumoniae was collected from sputum on Day 3. The patient seemed to have a co-infection of influenza virus and Streptococcus pneumoniae, and was administered 150 $\mathrm{mg}$ of oral oseltamivir for five days with intravenous biapenem of 1.0 g/day (Fig. 2).

Laboratory data improved: WBC count was $6,900 / \mathrm{mm}^{3}$ and CRP level was $19.59 \mathrm{mg} / \mathrm{dL}$ after adding sivelestat sodium hydrate, an inhibitor of neutrophil-derived elastase, from Day 2. However, chest X-ray findings and respiratory condition became worse on Day 8; $\mathrm{SpO}_{2}$ was $90 \%$ under $100 \% \mathrm{FiO}_{2}$, indicating deterioration. Because anti-microbial drugs did not work, we added intravenous methylprednisolone sodium succinate at $1 \mathrm{~g} /$ day to improve inflammation of the lungs and respiratory condition. The level of CRP decreased to $6.16 \mathrm{mg} / \mathrm{dL}$ and $\mathrm{SpO}_{2}$ of $94 \%$ under $60 \% \mathrm{FiO}_{2}$ improved on Day 10. However, chest X-ray findings did not change significantly, and acid-fast bacilli were detected from his sputum on Day 12, although no acid-fast bacilli had been detected in the sputum at the time of hospital admission, on Day 3, or on Day 7. Acid-fast staining revealed 3 on the Gaffky scale, and polymerase chain reaction assay confirmed genes of Mycobacterium tuberculosis in the sputum.

Intranasal administration of the anti-tuberculosis drugs isoniazid, rifampicin, ethambutol hydrochloride, and pyrazinamide was started and continued until Day 20; however, 

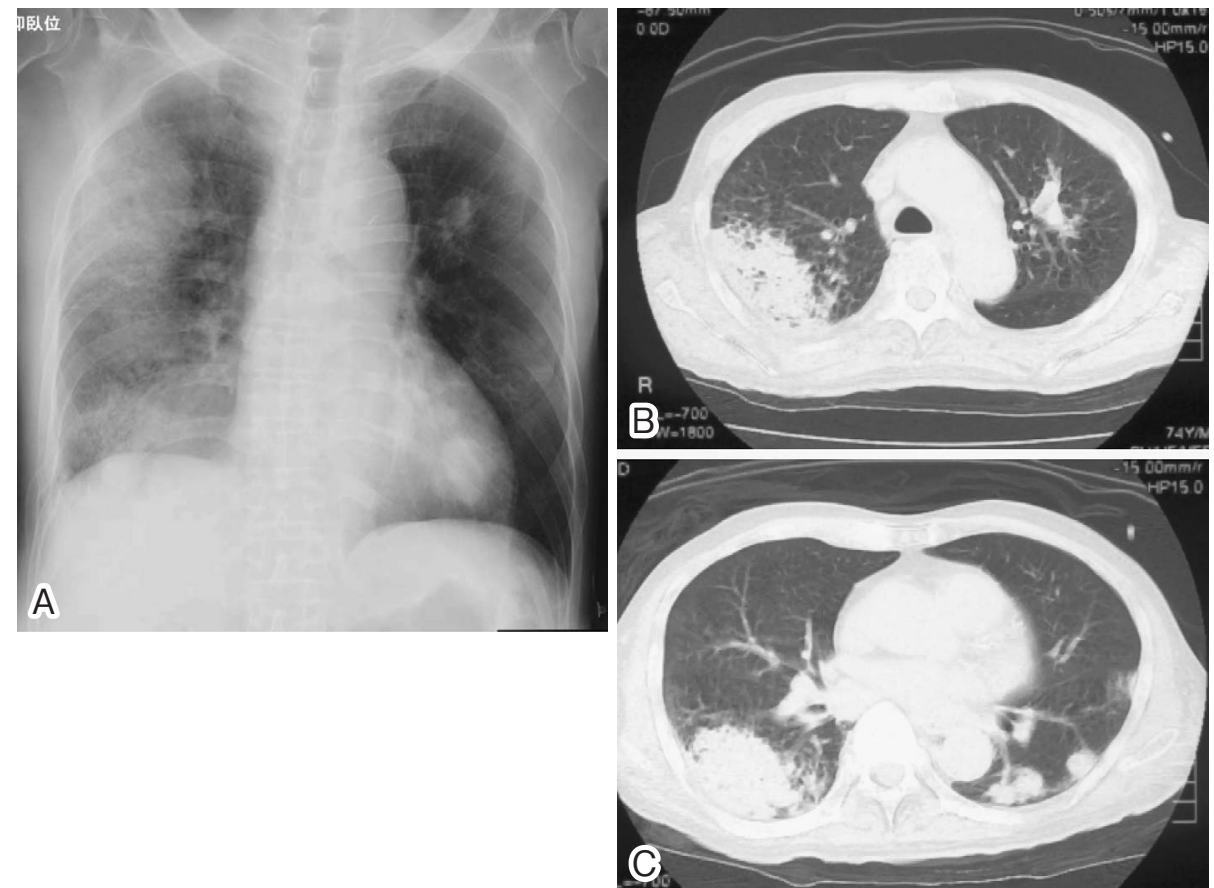

Figure 1. Chest X-ray (A) and chest computed tomogram (B), (C) of the patient upon admission. A. Massive consolidation of the right lung and a nodular shadow on the left lung are seen. B, C. Consolidation is evident in the right lung field and nodular consolidations are seen in the left lung field.

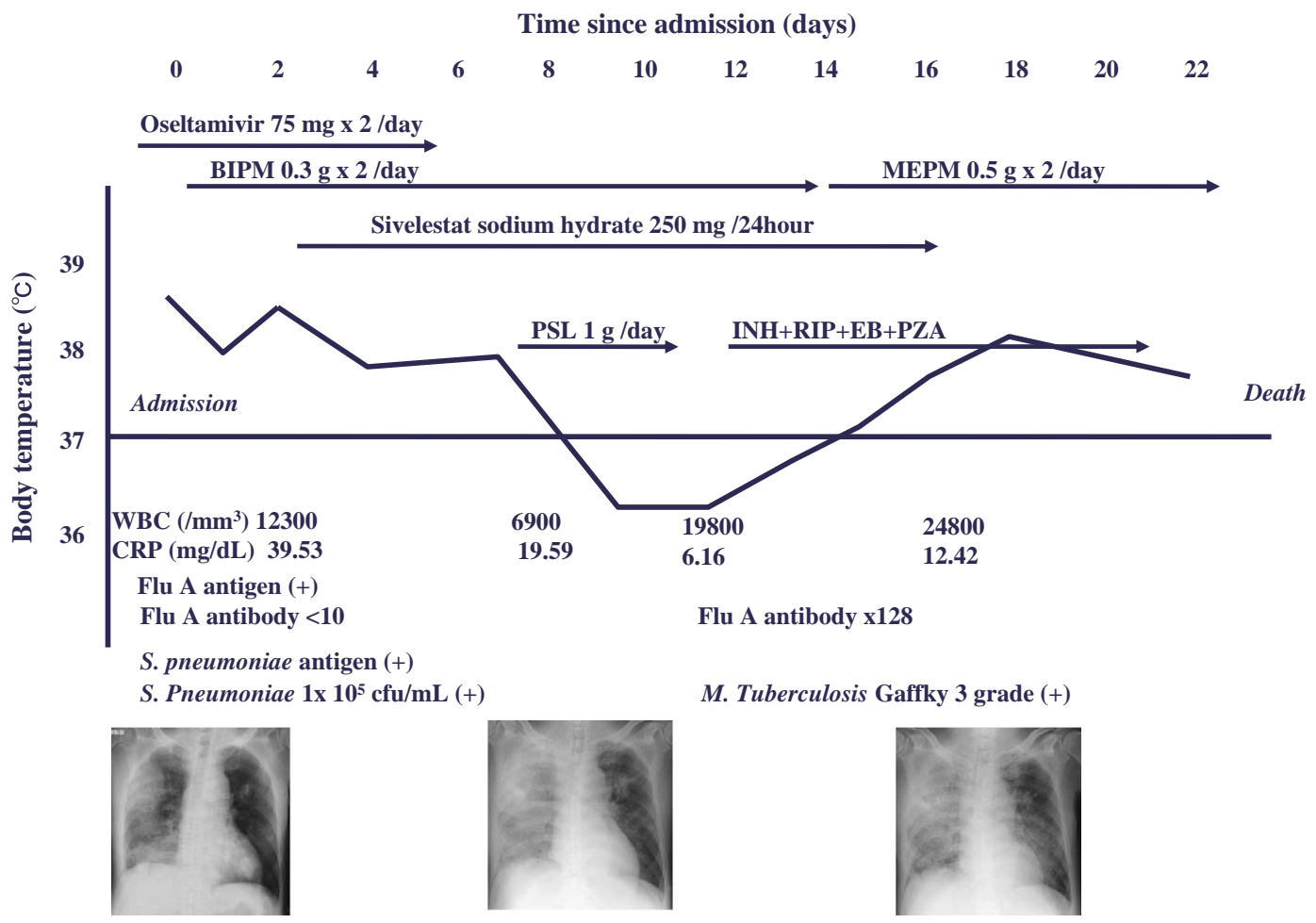

Figure 2. Clinical course of the patient after admission. PSL: methylprednisolone sodium succine, BIPM: biapenem, INH: isoniazid, RIP: rifanpicin, EB: ethambutol, PZA: pyrazinamide, MEPM: meropenem trihydrate.

the patient died of respiratory failure and severe pneumonia on Day 22. Mycobacterium tuberculosis was cultured from sputum and the final diagnosis was influenza virus-related bacterial pneumonia due to co-infection with Streptococcus pneumoniae followed by Mycobacterium tuberculosis infection. 


\section{Discussion}

Influenza A virus accounts for significant morbidity and mortality despite major efforts in prevention and treatment $(1,2,4)$. Morbidity and mortality have been attributed to the development of respiratory complications, including pneumonia. Rapid diagnostic tests have recently allowed confirmation of a tentative diagnosis of influenza virus pneumonia in patients with pneumonia acquired from the community $(1,2,4,9)$.

Here, a rapid detection kit identified the influenza virus antigen from a nasopharyngeal swab taken upon admission. The patient had yellow sputum and lancet-shaped grampositive diplococci with phagocytosis was found by gram staining. Streptococcus pneumoniae antigen was also detected in urine at the time of hospital admission, and $1 \times 10^{5}$ $\mathrm{cfu} / \mathrm{ml}$ of Streptococcus pneumoniae was collected from sputum on Day 3. We did not find any other bacilli by Gram staining and culture from sputum. Chest X-ray findings showed a massive infiltrative shadow; from these findings, influenza-related bacterial pneumonia due to Streptococcus pneumoniae was suspected. The results of a urinary antigen test for Legionella spp. were negative. Treatment with anti-viral drugs plus antibiotics worked, although additional steroid and sivelestat sodium hydrate were needed.

Unfortunately, we did not detect Streptococcus pneumoniae from blood culture, but pretreatment blood cultures yielded positive results for a probable pathogen in $5-14 \%$ in large series of nonselected patients hospitalized with CAP (1).

Furthermore, probable diagnosis was defined by a compatible clinical syndrome with detection (by staining or culture) of a likely pulmonary pathogen in respiratory secretions (expectorated sputum, bronchoscopic aspirate, or quantitatively cultured bronchoscopic bronchoalveolar lavage [BAL] fluid or brush catheter specimen) with semiquantitative culture, in which the pathogen should be recovered with moderate $(2+)$ to heavy growth $(3+)(2)$. These data suggested Streptococcus pneumoniae was one of the important pathogens of the pneumonia in this patient.

Influenza virus-related bacterial pneumonia is about three times more frequent than primary viral pneumonia (7). The most commonly involved bacteria are Staphylococcus aureus, Streptococcus pneumoniae, and Haemophilus influenzae. The reported fatality rate of Streptococcus pneumoniae co-infection is similar to that of community-acquired pneumonia (7). Virus infection in the respiratory tract appears to create favorable growth conditions for bacteria and some bacteria strains secrete a protease that exerts a decisive influence on the outcome of influenza virus infection by activating cleavage of viral hemagglutinin (8). Furthermore, influenza virus infection accelerates the activity of plateletactivating factor receptor, which is known as an anchor for Streptococcus pneumoniae, in bronchial tracts (10). These data suggest that an extant influenza virus infection plays a key role in the pathogenesis of these lethal lung diseases and in synergic effects between viral and bacterial infections.

Influenza virus itself was not isolated, although influenza virus $\mathrm{A}$ antigen was detected by a rapid detection kit at the time of hospital admission and a significant increase in influenza A antibody was found in the serum on Day 12 . The titer of influenza virus A antibody in serum was $\mathrm{x} 128$ on Day 12 in spite of $<10$ titer of the antibody on admission. These data strongly suggested influenza virus infection and its contribution to the pathogenesis of severe pneumonia in this patient.

A case of fulminant primary influenza pneumonia that developed into secondary bacterial pneumonia has been reported (11), and an increase in bacterial pneumonia severity due to co-infection with influenza virus has been reported (12). These synergic effects might be enhanced by host factors mediated through immunological reactions, including activations of innate immunities and neutrophils, as we previously reported (13-17).

Despite transient improvement and the administration of a steroid, the condition of this patient worsened again and he finally died only a few days after the detection of Mycobacterium tuberculosis in sputum. Ineffectiveness of the steroid and the appearance of tuberculosis made us suspect additional severe alveolar damage. Mycobacterium tuberculosis was first collected from the sputum on Day 12. We had performed specific staining and culture for Mycobacterium tuberculosis at the time of hospital admission, on Day 3, and on Day 7, but did not detect any acid-fast bacilli in the sputum (data not shown). Furthermore, we did not find typical findings of pulmonary tuberculosis, such as cavity formations and satellite lesions on X-ray and CT at the time of admission. These data suggested that the patient had a reactivation of tuberculosis infection in his immunecompromised condition that was facilitated by steroid administration for severe respiratory failure.

We did not perform a QFT-2 G assay, but a slightly positive result of a tuberculin skin test (a reddish site $10 \mathrm{~mm}$ in diameter, but no indurations) was found at the time of admission. This also suggested that pulmonary tuberculosis was not present at the time of admission, but was reactivated after steroid administrations.

Tuberculosis after influenza pneumonia has not been reported and is very rare; however, tuberculosis arthritis of the knee with Staphylococcus superinfection has been reported (18). Bacterial proteases, as well as the patient's immunecompromised status due to steroid administration and poorly controlled DM (HbA1c 11.7\%), might have reactivated tuberculosis. During the administration of steroid, glucose levels in plasma were also controlled poorly: from 250-450 $\mathrm{mg} / \mathrm{dL}$ in spite of continuous drip infusion of insulin. Impairment of phagocytosis against bacteria has been reported in patients with type $2 \mathrm{DM}$ and poor glycemic control (19), and dysfunctional neutrophils due to DM were suggested recently in patients with Klebsiella pneumoniae spondylitis 
(20).

Previous severe alveolar damage due to viral and bacterial co-infection might contribute to more severe infections, such as tuberculosis. In this case, we tried to perform brochoalveolar lavage and transbronchial lung biopsy by the bronchoscopic method to analyze the inflammatory cells and tissue damage, but we could not because of the patient's severe respiratory condition upon admission.

In conclusion, we identified a patient with severe influenza-related bacterial pneumonia due to Streptococcus pneumoniae that developed into an additional Mycobacterium tuberculosis infection. This was a rare case in which additional tuberculosis infection was found in one patient with fulminant pneumonia due to co-infection of influenza virus and bacteria. These two types of bacteria might have different pathogeneses, but both can be related to influenza virus infection and become severe and fatal. Further studies of the pathogenesis and treatment of viral infection and bacterial pneumonia followed by tuberculosis infection are required.

\section{References}

1. Mandell LA, Wunderink R, Anzueto A, et al. Infectious Diseases Society of America; American Thoracic Society. Infectious Diseases Society of America/American Thoracic Society consensus guidelines on the management of community-acquired pneumonia in adults. Clin Infect Dis 44: S27-S72, 2007.

2. Bartlett JG, Dowell SF, Mandell LA, File TM Jr, Musher DM, Fine MJ. Practice guidelines for the management of communityacquired pneumonia in adults. Infectious Diseases Society of America. Clin Infect Dis 31: 422-425, 2000.

3. Woodhead M, Blasi F, Ewig S, et al. Guidelines for the management of adult lower respiratory tract infections. Eur Respir J 26: 1138-1180, 2005.

4. Glezen WP, Greenberg S, Atmar RL, Piedra PA, Couch RB. Impact of respiratory virus infections on persons with chronic underlying conditions. JAMA 283: 499-505, 2000.

5. Gerberding JL, Morgan JG, Shapard JO, Kradin RL. An 18-yearold man with respiratory symptoms and shock. N Engl J Med 350: 1236-1247, 2004.

6. Yeldandi AV, Colby T. Pathologic features of lung biopsy specimens from influenza pneumonia cases. Hum Pathol 25: 47-53, 1994.

7. Robertson L, Caley J, Moore J. Importance of Staphylococcus aureus in pneumonia in the 1957 epidemic of influenza A. Lancet 2: 233-236, 1958.

8. Tashiro M, Ciborowski P, Klenk HD, Pulverer G, Rott R. Role of Staphylococcus protease in the development of influenza pneumonia. Nature 325: 536-537, 1987.

9. Marcante R, Chiumento F, Palu G, Cavedon G. Rapid diagnosis of influenza type A infection: comparison of shell-vial culture, directigen flu-A and enzyme-linked immunosorbent assay. New Microbiol 19: 141-147, 1996.

10. Mc Cullers JA, Rehg J. Lethal synergism between influenza virus and Streptococcus pneumoniae: characterization of a mouse model and the role of platelet-activating factor receptor. J Infect Dis 186: 341-350, 2002.

11. Seki M, Hashiguchi K, Kosai K, et al. A patient with fulminant primary influenza pneumonia which developed into secondary bacterial pneumonia. Acta Medica Nagasakiensia 51: 121-124, 2006.

12. Seki M, Kosai K, Yanagihara K, et al. Disease severity in patients with simultaneous influenza and bacterial pneumonia. Intern Med 46: 953-958, 2007.

13. Seki M, Yanagihara K, Higashiyama $\mathrm{Y}$, et al. Immunokinetics in severe pneumonia due to influenza virus and bacteria coinfection in mice. Eur Respir J 24: 143-149, 2004.

14. Seki M, Higashiyama Y, Tomono K, et al. Acute infection with influenza virus enhances susceptibility to fatal pneumonia following Streptococcus pneumoniae infection in mice with chronic pulmonary colonization with Pseudomonas aeruginosa. Clin Exp Immunol 137: 35-40, 2004.

15. Kosai K, Seki M, Yanagihara K, et al. Elevated levels of high mobility group box chromosomal protein-1 (HMGB-1) in sera from patients with severe bacterial pneumonia coinfected with influenza virus. Scand J Infect Dis 4: 1-5, 2007.

16. Kosai K, Seki M, Yanagihara K, et al. Two-dimensional gel electrophoresis analysis in simultaneous influenza pneumonia and bacterial infection in mice. Clin Exp Immunol 152: 364-371, 2008.

17. Kosai K, Seki M, Yanagihara K, et al. Gabexate mesilate suppresses influenza pneumonia in mice through inhibition of cytokines. J Int Med Res 36: 322-328, 2008.

18. Opara TN, Gupte C, Liyanage SH, Poole S, Beverly MC. Tuberculous arthritis of the knee with Staphylococcus superinfection. J Bone Joint Surg Br 89: 664-666, 2007.

19. Lin JC, Siu LK, Fung CP, et al. Impaired phagocytosis of capsular serotypes $\mathrm{K} 1$ or K2 Klebsiella pneumoniae in type 2 diabetes mellitus patients with poor glycemic control. Clin Endocrinol Metab 91: 3084-3087, 2006.

20. Kosai K, Seki M, Yanagihara K, et al. Spontaneous pyogenic spondylitis caused by Klebsiella pneumoniae. Intern Med 47: 1121-1124, 2008.

(C) 2008 The Japanese Society of Internal Medicine http://www.naika.or.jp/imindex.html 